\title{
ANALISIS FAKTOR PENYEBAB TINGGINYA ANGKA CERAI GUGAT PADA MASA PANDEMI COVID-19 DI KOTA PALEMBANG
}

\author{
Dr. Derry Angling Kesuma. SH.,M. Hum ${ }^{1}$ \\ Rohman Hasyim. SH.,M. MH ${ }^{2}$ \\ Kesumaderry@gmail.com \\ Fakultas Hukum Sekolah Tinggi Ilmu Hukum Sumpah Pemuda
}

\begin{abstract}
Abstrak: Faktor penyebab terjadinya perceraian pada masa pandemi Covid 19karena beberapa faktor yaitu, karena faktor zina, mabuk, madat, judi, meninggalkan salah satu pihak, dihukum penjara, poligami, KDRT, cacat badan, perselisihan atau pertengkaran terus menerus, kawin paksa, murtad, dan ekonomi. Dan faktor paling dominan adalah faktor perselisihan atau pertengkaran terus menerus. Faktor selanjutnya adalah karena meninggalkan salah satu pihak. Strategi pencegahan dan penanggulangan terjadinya cerai gugat tidak hanya tanggung jawab pemerintah. Hal ini disebabkan karena perceraian bersifat multidimensional sehingga aspek sosial, kultural, dan moral, serta semua unsur potensi dan pranata sosial dalam komunitas lokal juga berperan dalam menanggulangi bahkan mencegah terjadinya perceraian. Keluarga menjadi pendekatan yang merangkul calon suami istri memberikan pendidikan tentang keluarga. Sebab keluarga memiliki delapan fungsi, meliputi fungsi agama, sosial budaya, cinta kasih, perlindungan, reproduksi, sosialisasi dan pendidikan, ekonomi, dan lingkungan. Fungsi agama mengajarkan cara beribadah sesuai agamanya. Fungsi sosial mengajarkan nilai-nilai luhur budaya bangsa yang harus dilestarikan. Fungsi cinta kasih mengajarkan saling mengasihi antar anggota keluarga. Fungsi perlindungan melindungi dari ancaman fisik maupun psikis.
\end{abstract}

Kata Kunci: Faktor Penyebab Perceraian, Pandemi Covit 19, Strategi

\begin{abstract}
Factors causing divorce during the Covid-19 pandemic due to several factors, namely, fornication, drunkenness, oppression, gambling, leaving one party, sentenced to prison, polygamy, domestic violence, disability, continuous disputes or quarrels, forced marriage, apostasy, and economy. And the most dominant factor is the constant dispute or quarrel. The next factor is due to leaving one of the parties. The strategy of preventing and overcoming divorce is not only the responsibility of the government. This is because divorce is multidimensional so that social, cultural and moral aspects, as well as all elements of potential and social institutions in the local community also play a role in overcoming and even preventing divorce. Family is an approach that embraces prospective husbands and wives providing education about family. Because the family has eight functions, including the functions of religion, socio-culture, love, protection, reproduction, socialization and education, economy, and the environment. The function of religion is to teach how to worship according to their religion. The social function teaches the noble values of the nation's culture that must be preserved. The function of love teaches one another to love each other among family members. The function of protection protects from physical and psychological threats.
\end{abstract}

Keywords: Factors Causing Divorce, COVID-19 Pandemic, Strategy

\footnotetext{
${ }^{1}$ Penulis adalah Dosen Tetap Pada STIHPADA

${ }^{2}$ Penulis adalah Dosen Tetap Pada STIHPADA
} 


\section{LATAR BELAKANG}

Perceraian adalah pemutusan tali perkawinan karena suatu sebab yang disahkan oleh keputusan hakim atas tuntutan dari salah satu pihak atau kedua belah pihak $^{3}$ (Simanjuntak, 2007). Perceraian terjadi karena ada suatu alasan yang melatarbelakanginya. Saat ini, kasus perceraian di Indonesia masih terjadi dan terus meningkat jumlahnya. Jumlah kasus perceraian juga mengalami peningkatan selama pandemi Covid-19. Berdasarkan data Mahkamah Agung, pendaftaran perceraian yang mulanya berjumlah 20 ribu kasus padaperiode April dan Mei 2020 melonjak menjadi 57 ribu kasus pada Juni dan Juli 2020. ${ }^{4}$ Jika ditinjau lebih lanjut, peningkatan kasus perceraian yang paling banyak mengalami kenaikan adalah di Provinsi Jawa Tengah. Berdasarkan dataMahkamah Agung, pendaftaran perceraian yang mulanya berjumlah 20 ribu kasus padaperiode April dan Mei 2020 melonjak menjadi 57 ribu kasus pada Juni dan Juli 2020.

Pengadilan Agama Palembang, Sumatera Selatan, mencatat selama masa pandemi Covit 29 sejak April 2020 Hingga Agustus 2020, telah menangani perkara perceraian sebanyak 1.666 Perkara. ${ }^{5}$ Menurut Kepala Panitera Pengadilan Agama Kelas 1A Palembang, Bapak Taftazani bahwa Perkara perceraian yang ditangani Pengadilan Agama Palembang sebagian besar diajukan istri atau lazim disebut dengan Cerai Gugat. Taftazani menjelaskan perincian perkara perceraian yang ditangani selama masa Pandemi Covit 19 sebanyak 1.284 perkara Cerai gugat dan 383 perkara Cerai Talak.

Pandemi Covid-19 memiliki dampak yang besardalam kehidupan keluarga. Untuk memutus penyebaran virus Covid-19 pemerintah menetapkan kebijakan Pembatasan Sosial Berskala Besar. Kebijakan ini menuntut keluarga untuk melakukan aktivitas dari rumah, mulai dari belajar, beribadah hingga bekerja. Keadaan ini membuat masing-masing anggota keluarga menghabiskan lebih banyak waktunya di rumah. Kondisi ini disikapi berbeda oleh tiap- tiap keluarga.

\footnotetext{
${ }^{3}$ https://www.google.com/search?q=angka+perceraian+di+kota+palembang+2021\&oq=ang ka+perceraian+di+kota+palembang $+2021 \& a q s=$ chrome. $.69 i 57.4823 j 0 j 7 \&$ sourceid=chrome $\& i e=U$ $\underline{\mathrm{TF}-8}$, diakses pada tanggal 12 Februari 2021

${ }^{4}$ Ibid

${ }^{5}$ https://www.antaranews.com/berita/1759145/masa-pandemi-pengadilan-agamapalembang-tangani-1666-perkara-cerai, diakses pada tanggal 01 Juni 2021
} 
Ada yang menyikapinya dengan positif seperti membangun kembali kebersamaan dan kedekatan antar anggota keluarga. Namun, ada juga yang menyikapinya secara negatif hingga berujung pada konflik. Adapun aspek yang paling banyak menjadi bahan perdebatan antar pasangan suami istri sekaligus menjadi sumber konflik yaitu dari sisi ekonomi.

Hasil penelitian BKKBN dan IPB pada tahun 2020 mengungkapkan, ${ }^{6}$ pada masa pandemi Covid-19 pola hidup keluarga dalam bidang ekonomi, pekerjaan, hingga ketercukupan kebutuhan primer semakin memburuk. Penelitian di Cina juga menunjukkan hasil yang sama bahwa pada fase awal pandemi Covid-19 lebih dari separuh masyarakat mengalami dampak psikologis berupa stres, kecemasan, dan depresi dari tingkat sedang hingga berat. ${ }^{7}$ Begitu pula penelitian Luo et al, salah satu penyebab kecemasan yang dialami para keluarga yaitu karena tidak stabilnya pendapatan. Banyak pasangan yang mengalami masa-masa sulit. Mereka tidak mampu mengelola stres dan menghadapi ketidakpastian serta kecemasan. Hal ini memicu pada kekerasan instrumental yang diperparah dengan peningkatan penggunaan obat-obatan dan alkohol sebagai strategi untuk menghadapi tingkat stres yang luar biasa. ${ }^{8}$

Perubahan ekonomi yang terjadi akibat pandemi Covid-19 tidak mampu diterima oleh semua keluarga. Ada keluarga yang tidakmemiliki cukup tabungan untuk menghadapi kondisi darurat. Akhirnya konflik kerap terjadi, masing-masing memiliki keinginan serta gagasan yang ingin diakui dan dilaksanakan, sementara pihak lainnya memiliki harapan yang berbeda. Ego dan pengakuan tinggi kadang sulit dibendung di antara pasangan suami dan istri. Ada yang mampu mengatasi konflik tersebut dengan baik, namun ada juga yang membuat permasalahan tersebut semakinberlarut-larut. Hal menyebabkan ketahanan keluarganya menjadi lemah dan berakhir pada perceraian.

${ }^{6}$ Darmawati, H. Perceraian Dalam Perspektif Sosiologi, Volume 11 Nomor 1 Tahun 2017, Sulesana, 2017,hlm. 10

${ }^{7}$ Ibid

8 Sakroni, Penyebab Perceraian Di Jawa Barat Pada Masa Pandemi COVID-19. Disampaikan dalam Webinar 7 th Internasioanal Academia rountable forum, 25 Juli 2020, hlm. 3 
Bencana dan ketahanan keluarga menjadi hal yang tidak terpisahkan. Bencana dapat berdampak negatif pada keutuhan keluarga. Seperti hasil penelitian di Carolina Selatan yang menunjukkan bahwa perkawinan dan kelahiran menurun sementara perceraian meningkat di negara-negara yang terkena dampak badai hugo. ${ }^{9}$ Kemudian hasil penelitian di Taiwan, salah satu faktor risiko yang signifikan untuk depresi mayor akibat gempa adalah bercerai/janda. Lebih lanjut, survei di Austria tentang pandemi Covid-19 dan kualitas hubungan pasangan memberikan hasil bahwa individu dengan kualitas hubungan yang baik cenderung memiliki kesehatan mental yang positif dibandingkan individu dengan kualitas hubungan buruk atau tanpa hubungan.

Suatu kehidupan rumah tangga harus ada kesadaran untuk saling memahami, menghormati, menghargai, dan menjaga keharmonisan. Semakin dirugikannya seseorang dalam kehidupan rumah tangganya, maka akan semakin besar potensi untuk bercerai. Teori Exchange George Homans ${ }^{10}$ menjelaskan semakin bernilai dan bermakna tingkah laku seseorang yang ditujukan kepada pasangannya, maka akan semakin besar kemungkinan tingkah laku tersebut diulangi. Dalam rumah tangga, ketika istri menunjukkan kasih sayang, kebaikan, dan perhatian kepada suami dan direspon dengan baik, misal membelikan barangbarang kesukaan istrinya, maka tingkah laku tersebut akan diulang terus oleh istri. Namun, bila ganjaran yang diberikan monoton dan tidak bervariasi maka akan berkurang nilai daritingkah laku tersebut.

Merujuk pada hukum Gossen II, semakin sering seseorang menerima ganjaran akan tindakan dari orang lain, semakin berkurang nilai dari setiap tindakan yang dilakukan berikutnya. Dalam kehidupan rumah tangga, idealnya masing-masing pasangan memiliki kepekaan dan memahami kesukaan masingmasing agar tidak terjadi kejenuhan dan berkurangnya nilai yang diberikan. Dampaknya menurut Teori Exchange Homans (2004), semakin dirugikan seseorang dalam hubungannya dengan orang lain maka semakin besar 


\section{Jurnal Tripantang}

Falkultas Hukum Universitas Tamansiswa Palembang

kemungkinan orang tersebut akan mengembangkan emosi negatif misalnya marah.

Untuk menyikapi peningkatan kasus perceraian, pemerintah telah melakukan berbagai upaya preventif. Upaya pertama dilakukan dengan cara pembatasan usia perkawinan, batasan bagi laki-laki dan perempuan di atas 19 tahun. Lebih lanjut, Badan Kependudukan dan Keluarga Berencana Nasional sebagai lembagapemerintah yang fokus pada persoalan kependudukan baik secara kuantitas maupunkualitas memiliki batasan sendiri dalam hal pernikahan yakni 21 tahun bagi perempuan dan 25 tahun bagi laki-laki. Pertimbangan 21 tahun bagi perempuan karena organ-organ reproduksi perempuan di atas usia 20 tahun sudah matang dan siap untuk dibuahi sehingga cocok untuk menikah. Pertimbangan lainnya pada usia tersebut para pasangan diharapkan sudah memiliki pendapatan sehingga sudah siap dari sisi ekonomi.

Berdasarkan data dari Direktorat Jenderal Badan Peradilan Agama (Badilag) Mahkamah Agung, tren angka perceraian setiap tahunnya mengalami peningkatan terutama sejak masa krisis ekonomi pada tahun 1997-1998. Pada saatitu, angka putusan cerai gugat lebih tinggi dibanding cerai talak. Kebanyakan alasan pihak istri mengajukan gugatan cerai lantaran banyak mengalami ketidakharmonisan dalam kehidupanrumah tangga. Direktur Lembaga Bantuan Hukum (LBH) APIK, Venny Octarini Siregar, mengakui pengajuan gugatan cerai seringkali dilakukan oleh pihak istri. Salah satu sebabnya, perempuan dan anak kerapkali menjadi korban dari kekerasan dalam rumah tangga ${ }^{11}$. Fenomena yang pernah terjadi pada tahun 1997-1998 kembali terjadi pada masa pandemi coronavirus disease 2019 (COVID-19). Hal tersebut dapat dilihat dari data yang dilansir oleh suara.com, pada bulan Juni hingga Juli 2020, diketahui bahwa jumlah perceraian meningkat,

\footnotetext{
${ }^{11}$ Rofiq, H. (2020). Melihat Tren Perceraian danDominasi Penyebabnya. (18 Juni 2020)https://www.hukumonline.com/berita/ baca/lt5b1fb923cb04f/melihat-tren. Diakses23 Desember 2020
} 
di mana 80 persen kasus gugatan cerai yang masuk ke pengadilan agama diajukan oleh pihak istri. ${ }^{12}$

Meningkatnya angka perceraian menjadi pekerjaan rumah bagi pemerintah untuk mencari solusi agar keutuhan keluarga tetap dapat terjagadi tengah pandemi. Apabila keutuhan keluarga tidak dapat dijaga maka keluarga tersebut akan sulit menghadapi tantangan di era sekarang dan akan datang. Oleh sebab itu perlu adanya kerjasama antara berbagai pihak dalam mewujudkan hal tersebut. Hal tersebutlah yang kemudian menarik minat penulis untuk menelitinya secara lebih mendalam kedalam sebuah tulisan berjudul : "Analisis Faktor Penyebab Tingginya Angka Cerai Gugat Pada Masa Pandemi Covid-19 Di Kota Palembang".

Berdasarkan latar belakang masalah di atas, maka penulis mencoba menganalisis fenomena meningkatnya kasus perceraian di masa pandemi COVID19 dalam perspektif ilmu sosial dan hukum, dimana permasalahan yang akan saya angkat adalah apasaja yang menjadi penyebab tingginya angka Cerai Gugat di Kota Palembang pada masa Pandemi Covid 19 dan upaya apa yang dapat dilakukan untuk meminimalisir perceraian tersebut?

\section{METODE}

Peneliti menggunakan pendekatan kualitatif, yaitu campuran berbagai sumber data dan berbagai metode. Penelitian ini adalah penelitian lapangan (field research), dimana peneliti terjun langsung ke lapangan guna untuk melakukan wawancara, serta melakukan pengumpulan dokumen, yang mana penelitian tersebut dilakukan di Pengadilan Agama Palembang. Berdasarkan objek kajian, tulisan dilakukan dengan cara mengumpulkan data, informasi dengan cara menelaah sumber-sumber tertulis seperti jurnal ilmiah, buku referensi, literatur, ensiklopedia, karangan ilmiah, serta sumber-sumber lain yang terpercaya baik 
dalam bentuk tulisan atau dalam format digital yang relevan tanpa harus turun langsung ke lapangan. Tulisan ini diharapkan memberikan manfaat dan masukan, serta menjadi bahan pertimbangan bagi para pengambil keputusan dalam rangka mengkaji dan menetapkan berbagai kebijakan terkait pandemi COVID-19.

\section{PEMBAHASAN DAN ANALISIS}

\section{Penyebab Tingginya Angka Cerai Gugat Di Kota Palembang Pada Masa Pandemi Covit 19}

Dalam Islam menginginkan pasangan suami istri yang telah membina suatu rumah tangga melalui akad nikah adalah bersifat langgeng. Terjalin keharmonisan di antara suami istri yang saling mengasihi dan menyayangi itu sehingga masingmasing pihak merasa damai dalam rumah tangga. Rumah tangga seperti ini yang diinginkan Islam, yaitu rumah tangga sakinah. Ada tiga kunci mencapai kehidupan rumah tangga yang ideal dan bahagia menurut agama Islam, yaitu sakinah (as-sakinah), mawaddah (al-mawaddah), dan rahmat (ar-rahmah). Ulama tafsir menyatakan bahwa as-sakinah adalah suasana damai yang melingkupi rumah tangga yang bersangkutan, masing-masing pihak menjalankan perintah Allah SWT dengan tekun, saling menghormati, dan saling toleransi. ${ }^{13}$

Dari suasana as-sakinah tersebut akan muncul rasa saling mengasihi dan menyayangi (al-mawaddah), sehingga rasa tanggung jawab kedua belah pihak semakin tinggi. Sedangkan para mufasir mengatakan bahwa dari as-sakinah dan al-mawaddah inilah nanti muncul ar-rahmah, yaitu keturunan yang sehat dan penuh berkat dari Allah SWT, sekaligus sebagai pencurahan rasa cinta dan kasih suami istri dan anak-anak mereka nantinya. ${ }^{14}$

Pada dasarnya suatu perkawinan itu dilakukan untuk waktu selamanya sampai akhir hayat, inilah yang dikehendaki dalam agama Islam. Namun dalam

${ }^{13}$ Agustina Nurhayati, "Pernikahan Dalam Perspektif Al-Qur'ean," Jurnal Asas, Vol. 1, No. 1 (Januari 2001), hlm. 101.

${ }^{14}$ Ibid 
kondisi tertentu ada hal-hal yang menghendaki terjadinya putusnya perkawinan, dan jika hubungan perkawinan tetap dilanjutkan, maka kemudharatan akan terjadi. Dalam hal ini agama Islam membenarkan putusnya perkawinan sebagai langkah terakhir dari usaha melanjutkan rumah tangga. Putusnya perkawinan dengan begitu adalah suatu jalan keluar yang baik.

Bercerai adalah lepasnya ikatan dan dapat dipahami perceraian adalah putusnya ikatan perkawinan antara suami-istri dalam rangka membina rumah tangga yang utuh, kekal dan abadi, sehingga antara keduanya tidak halal lagi bergaul sebagaimana layaknya suami-istri. ${ }^{15}$ Di dalam Kompilasi Hukum Islam (KHI) pasal 117 di tegaskan talak adalah "ikrar suami di hadapan sidang Pengadilan Agama yang menjadi salah satu sebab putusnya perkawinan, dengan cara sebagaimana dimaksud dalam pasal 129, 130, dan 131.

Di dalam Kompilasi Hukum Islam (KHI) tidak diatur mengenai hal-hal yang bersangkutan tentang talak secara terperinci hanya terdapat masam-macam talak yaitu disebutkan pada pasal 118, 119, 121, 122 yaitu :

a. Pasal 118

Talak $R a j$ " $i$ adalah talak kesatu atau kedua, dimana suami berhakrujuk selama istri dalam masa iddah.

b. Pasal 119

Talak Ba"in Sughra adalah talak yang tidak boleh dirujuk tapiboleh akad nikah baru dengan bekas suaminya meskipun dalam iddah. Talak $\mathrm{Ba}^{\text {ee in }}$ Sughraa sebagaimana tersebut pada ayat (1) adalah: Talak yang terjadi qabla dan dukhul, Talak dengan tebusan atau khuluk dan Talak yang dijatuhkan oleh Pengadilan Agama.

c. Pasal 120

Talak Ba"in Kubraa adalah talak yang terjadi untuk ketiga kalinya. Talak jenis ini tidak dapat dirujuk dan tidak dapat dinikahkan kembali, kecuali apabila pernikahan itu dilakukan setelah bekas, istri, menikah dengan orang lain dan kemudian tejadi perceraian baeeda al dukhul dan hadis masa iddahnya.

d. Pasal 121

Talak sunni adalah talak yang dibolehkan yaitu talak yang dijatuhkan terhadap istri yang sedang suci dan tidak dicampuri dalam waktu suci tersebut.

${ }^{15}$ A.R.Idhama Kholid, "Di Persimpangan Jalan Antara Melanjutkan Perceraian Atau Memilih Rujuk Pada Masa Iddah,” Jurnal Insklusif, Vol. 1, Jakarta, 2016, hlm.6 


\section{e. Pasal 122}

Talak bid" $i$ adalah talak yang dibolehkan yaitu talak yang dilarang, yaitu talak yang dijatuhkan pada waktu istri yang sedang suci dan tidak dicampuri dalam waktu suci tersebut.

Cerai gugat adalah permintaan istri kepada suaminya melalui pengadilan untuk menceraikan (melepaskan) dirinya dari ikatan perkawinan dengan disertai atau tanpa ,iwadh (pengganti) berupa uang atau barang kepada suami. ${ }^{16}$ Berdasarkan Pasal 39 ayat (1) UU No. 1 Tahun 1974 jo. Pasal 115 KHI, perkawinan dianggap putus apabila telah diikrarkan talak di depan sidang Pengadilan Agama, setelah pengadilan tersebut berusaha dan tidak berhasil Pasal 39, sebagai berikut:

a. Perceraian hanya dapat dilakukan didepan sidang pengadilan;

b. Untuk melakukan perceraian harus ada cukup alasan bahwa antara suami dan istri itu tidak akan dapat rukun lagi sebagai suami istri.

Perceraian berdasarkan Pasal 114 KHI yaitu putusnya perkawinan yang disebabkan karena perceraian dapat terjadi karena talka, atau berdasarkan gugatan perceraian, namun lebih jelasnya dalam Pasal $116 \mathrm{KHI}$ dijelaskan beberapa alasan atau alasan-alasan perceraian yang akan diajukan kepada pengadilan untuk di proses dan ditindak lanjuti. Adapun alasan-alasan tersebut adalah :

a. Salah satu pihak berbuat zina atau menjadi pemabuk, pemadat, penjudi, dan sebagainya yang sukar di sembuhkan;

b. Salah satu pihak meninggalkan pihak lain selama dua tahun berturutturut tanpa izin pihak lain dan tanpa alasan yang sah atau karena hal lain diluar kemampuannya.

c. Salah satu pihak mendapat hukuman penjara selama lima tahun atau hukuman yang lebih berat selama perkawinan berlangusng.

d. Salah satu pihak melakukan kekejaman atau, penganiyayaan berat yang membahayakan pihak lain.

e. Salah satu pihak mendapatkan cacat badan atau penyakit dengan akibat

\footnotetext{
${ }^{16}$ Jefri Sulthonudin, M. Yustafad, Abd. Halim Musthofa, “Cerai Gugat Istri Akibat Suami Dipidana Penjara Menurut Perspektif Hukum Islam Dan Hukum Positif (Analisis Putusan Nomor. 609/Pdt.G/2018.PA.Kdr), Jurnal LEGITIMA Hukum Keluarga Islam, Vol. 2, No. 1 (Desember 2019), hlm. 2-3.
} 
tidak dapat menjalankan kewajibannya sebagai suami-istri.

f. Antara suami-istri terjadi perselisihan dan pertengkaran dan tidak ada harapan untuk hidup rukun lagi dalam rumah tangga.

g. Suami melanggar ta" lik talak

h. Peralihan agama atau murtad yang menyebabkan terjadinya ketidak rukunan dalam rumah tangga

Adapun yang dimaksud talak Pasal 117 Kompilasi Hukum Islam, talak adalah ikrar suami dihadapan Pengadilan Agama yang menjadi salah satu sebab putusnya perkawinan. Sedangkan yang dimaksud dengan perceraian adalah: ${ }^{17}$

a. Gugatan perceraian diajukan oleh istri atau kuasanya pada Pengadilan Agama, yang daerah hukumnya mewilayahi tempat tinggal penggugat, kecuali meninggalkan tempat kediaman bersama tanpa izin suami;

b. Dalam hal gugat bertempat kediaman di luar negeri, ketua Pengadilan Agama memberitahukan gugatan tersebut kepada tergugat melalui perwakilan Republik Indonesia setempat.

Dengan demikian dapat disimpulkan bahwa perceraian dengan jalan talak adalah permohonan cerai yang diajukan oleh suami, sedangkan gugatan perceraian diajukan oleh pihak istri atau kuasanya kepada Pengadilan Agama.

Pada bulan April sampai bulan Januari 2021 kasus perceraian di Pengadilan Agama Palembang meningkat secara tajam disebabkan oleh beberapa faktor, antara lain :

1. Ada faktor ekonomi;

2. kekerasan dalam rumah tangga (KDRT); Ada juga yang suaminya di penjara, itu juga termasuk faktor perceraian; Faktor inilah yang membuat kasus perceraian terjadi karena suami di penjara. Karena selama di penjara istri tidak mendapatkan nafkah dari seorang suami baik nafkah lahir maupun batin. Hal inilah yang menjadikan istri mengajuka cerai ke Pengadilan. Mungkin bagi istri ini adalah solusi terakhir yang dapat ditempuh istri dalam mengakhiri perkawinannya. Proses

${ }^{17}$ Linda Azizah, "Analisis Perceraian Dalam Kompilasi Hukum Islam," Jurnal Al„Adalah, No. 4, Vol. 10, (Juli, 2012), hlm. 421. 
3. Faktor media sosial, dimana kemudian salah satu pasangan lebih mengutamakan media sosial dibandingkan keutuhan rumah tangganya, dan keperluan dr kehidupan sehari-hari;

4. Perselingkuhan (zina) atau poligami;

5. Mabuk atau Madat, Dalam pasal $116 \mathrm{KHI}$ antara lain menjelaskan bahwa perceraian dapat terjadi karena salah satu pihak berbuat zina atau menjadi pemabuk, pemandat. Penjudi dan lain sebagainya yang sukar disembuhkan.

6. Judi, menjadi pemicu perselisihan dan pertengkaran yang terus menerus terjadi dalam kehidupan rumah tangga. Seorang suami yang sering berjudi menjadikan malas untuk bekerja dan selalu bersikap tempramental;

7. meninggalkan salah satu pihak, Kepergian pasangan suami dan/istri dalam waktu yang cukup lama, suami tidak pernah ada di rumah. Jika istri tidak bisa menerima keadaan itu dan merasa sangat dirugikan atas kepergian suaminya. Yang seharusnya suami memberikan nafkah lahir dan batin tetapi lari dari tanggung jawabnya. perceraian di Pengadilandapat dilakukan atas kehendak istri disebut cerai gugat. Untuk faktor dihukum penjara sedikit sekali jumlahnya, faktor ini juga tidak mendominasi terjadinya peningkatan kasus perceraian yang terjadi selama masa pandemi Covid 19.

Masa pandemi Covid 19 ini mempunyai pengaruh besar bagi kehidupan manusia, baik dalam bidang ekonomi, politik, dan sosial. Sehingga tidak bisa dipungkiri bahwa pengaruh Covid 19 mengenai penegakan hukum dibeberapa negara. Berdasarkan penelitian yang telah dilakukan di kota Palembang dapat diketahui bahwakasus perceraian mengalami peningkatan. Hal ini dapat diketahui dengan adanya beberapa faktor seperti yang diebutkan diatas, yakni mabuk, judi, selingkuh, ekonomi, salah satu pihak meninggalkan pasangannya yang menyebabkan pemicu kasus perceraian terjadi. 


\section{Upaya Untuk Meminimalisir Cerai Gugat Pada Masa Pandemi Covit 19 Di}

\section{Pengadilan Agama Palembang}

Seseorang yang merasa dirugikan dalam suatu hubungan cenderung akan meluapkan emosinya dengan marah. Marah menjadi bagian awal dari ketidakpuasan yang dialami. Karena berlarut-larut dan tidak menemukan titik temu maka berpisah menjadi langkah menyelesaikan ketidakadilan dalam hubungan rumah tangga.

Komunikasi bisa menjadi jembatan mengurangi perselisihan yang terjadi. Melalui komunikasi, dapat tersampaikan pikiran atau perasaan kepada orang yang dituju. Komunikasi berlaku apabila komunikator bermaksud memberitahukan sesuatu kepada orang lain. Lasswell mengungkapkan, ${ }^{18}$ cara terbaik saat akan melakukan proses komunikasi yaitu dengan memahami sumber pesan, isi, dan media/saluran. Terkadang komunikasi tidak berjalan baik dan mengalami kendala karena tidak memiliki saluran untuk menyampaikanya. Begitu pula dalam keluarga, ketika saling bersilang pendapat dan tidak ada jalan keluar, perlu mediator untuk menyampaikan pesan dari kedua pihak. Cepat atau lambatnya penyelesaian suatu masalah tergantung pada kemampuan mediator merespons dan menemukan titik penyelesaian sehingga terjadi interaksi. Menurut Ritzer kemampuan proses interaksi yang harmonis dan komunikasi yang baik antara suami istri meminimalisir konflik dan perceraian.

Strategi pencegahan dan penanggulangan perceraian tidak hanya tanggung jawab pemerintah. Hal ini disebabkan karena perceraian bersifat multidimensional sehingga aspek sosial, kultural, dan moral, serta semua unsur potensi dan pranata sosial dalam komunitas lokal juga berperan dalam menanggulangi bahkan mencegah terjadinya perceraian. Keluarga menjadi pendekatan yang merangkul calon suami istri memberikan pendidikan tentang keluarga. Sebab keluarga memiliki delapan fungsi, meliputi fungsi agama, sosial budaya, cinta kasih, perlindungan, reproduksi, sosialisasi dan pendidikan, ekonomi, dan lingkungan.

Fungsi agama mengajarkan cara beribadah sesuai agamanya. Fungsi sosial mengajarkan nilai-nilai luhur budaya bangsa yang harus dilestarikan. Fungsi cinta

\footnotetext{
${ }^{18}$ Ibid
} 
kasih mengajarkan saling mengasihi antar anggota keluarga. Fungsi perlindungan melindungi dari ancaman fisik maupun psikis. Fungsi reproduksi mengajarkan menjaga kesehatan organ reproduksi untuk melahirkan keturunan sehat. Fungsi sosialisasi dan pendidikan, memberikan pendidikan tingkat formal maunpun nonformal dalam mewujudkan cita-citanya. Fungsi ekonomi mengajarkan hidup hemat, suka menabung dan membeli berdasarkan kebutuhan. Fungsi lingkungan mengajarkan cara menjaga lingkungan, tidak membuang sampah sembarangan, menembang pohon secara liar sehinggalingkungan asri dan memenuhi kebutuhan manusia.

\section{KESIMPULAN}

Dari apa yang telah dijabarkan pada sub bab diatas, maka dapatlah penulis tarik kesimpulan sebagai berikut :

1. Faktor penyebab terjadinya perceraian pada masa pandemi Covid 19 karena beberapa faktor yaitu, karena faktor zina, mabuk, madat, judi, meninggalkan salah satu pihak, dihukum penjara, poligami, KDRT, cacatbadan, perselisihan atau pertengkaran terus menerus, kawin paksa, murtad, dan ekonomi. Dan faktor paling dominan adalah faktor perselisihan atau pertengkaran terus menerus. Faktor selanjutnya adalah karena meninggalkan salah satu pihak.

2. Strategi pencegahan dan penanggulangan terjadinya cerai gugat tidak hanya tanggung jawab pemerintah. Hal ini disebabkan karena perceraian bersifat multidimensional sehingga aspek sosial, kultural, dan moral, serta semua unsur potensi dan pranata sosial dalam komunitas lokal juga berperan dalam menanggulangi bahkan mencegah terjadinya perceraian. Keluarga menjadi pendekatan yang merangkul calon suami istri memberikan pendidikan tentang keluarga. Sebab keluarga memiliki delapan fungsi, meliputi fungsi agama, sosial budaya, cinta kasih, perlindungan, reproduksi, sosialisasi dan pendidikan, ekonomi, dan lingkungan. Fungsi agama mengajarkan cara beribadah sesuai agamanya. Fungsi sosial mengajarkan nilai-nilai luhur budaya bangsa yang harus dilestarikan. Fungsi cinta kasih mengajarkan saling mengasihi antar anggota keluarga. Fungsi perlindungan melindungi dari 
ancaman fisik maupun psikis.

\section{DAFTAR PUSTAKA}

Abror, Khoirul., Poligami dan Relevansinya dengan Keharmonisan Rumah Tangga (Studi Kasus di Kelurahan Rajabasa Bnadar Lampung). Jurnal Hukum dan Perundingan Islam, 2016

Arikunto, Suharsimi. Prosedur Penelitian, PT Rineka Cipta, Jakarta, 2010

Asmuni, 2010, Perceraian Dalam Perspektif Fikih Klasik dan Kompilasi Hukum Islam, Jurmal Warta, Edisi 48

Azizah, Linda, Analisis Perceraian dalam Kompilasi Hukum Islam, Jurnal Al„Adalah, Vol. 10, No. 4. 2012

Azwar, Saifuddin, Metodologi Penelitian Kualitatif, Pustaka Pelajar Offset, Bandung, 1998

Basyir, Ahmad Azhar, Hukum Perkawinan Islam, Edisi ke-1. Cet. Ke-9. UII, Yogyakarta, 1999.

Harjianto, Roudhotul Jannah, Identifikasi Faktor Penyebab Perceraian Sebagai Dasar Konsep Pendidikan Pranikah di Kabupaten Banyuwangi, Jurnal Ilmiah Universitas Batanghari Jambi, Vol. 19, No. 1.

J. Moleong, Lexy, Metodologi Penelitian, Pustaka Pelajar Offset, Yogyakarta, 2017

Kholid, A. R Idhama, Di Persimpangan Jalan antara Melanjutkan Perceraian Atau Memilih Rujuk pada Masa Iddah, Jurnal Insklusif, PT Rineka Cipta, Vol. 1. 2016

Kusuma, Lidiya, Praktik Perceraian di Desa Prabumulih Kecamatan Muara Lakitan Kabupaten Musi Rawas, Jurnal Raden Fatah Intelektualita, Vol. 5, No. 2. 2016

Novitasari, Choirunnisa Nur, dkk. Analisis Hukum Islam terhadap Faktor Putusnya Tali Perkawinan, Jurnal Hukum Keluarga dan Hukum Islam, Vol. 3, No. 2. 2009

Nurhayati, Agustina, Pernikahan Dalam Perspektif Al-Qur"an, Jurnal ASAS. Volume 1. Nomor 1. 2001

Sa"eadah, Mazro"atus., Pembuktian Perzinaan dalam Perceraian menurut AlQur"an dan Hukum Acara Perdata, Jurnal Hukum dan Perundingan Islam, 2014 